\title{
Tourism development and regional disparities in Serbia
}

\author{
Jasna Micić \\ Geographical Institute Jovan Cvijić SASA, Belgrade, Serbia; e-mail: j.micic@gi.sanu.ac.rs
}

\section{ABSTRACT}

This paper discusses regional disparities and general national trends in the development of tourism industry in Serbia. Serbia has a rich and well-preserved cultural and natural heritage, which means that this country holds significant potential for the development of tourism. Our analysis assessed the dynamics of tourism development by using census data and focusing on such indicators as the population size of different regions, the share of people employed in tourism, the proportion of economically active population and tourism traffic (the number of foreign tourists and overnight stays). All indicators were analyzed by calculating the index of change. The results show that in Serbia, tourism has not yet achieved an adequate level of development and plays a secondary role in the country's economy even though it could contribute to the demographic revitalization of Serbian regions. There is also a steady growth in the number of people employed in the tourism sector. Among other Serbian regions, Belgrade has the most thriving tourism industry due to its status of the capital city. Other regions also demonstrate significant growth in the traffic of foreign tourists, especially Zlatibor, Moravica, and Toplica. Adequate management and promotion of these destinations on the international tourism market have proven to be quite effective.
\end{abstract}

\section{KEYWORDS}

tourism, economic evaluation, unbalanced regional development, regional disparities, Serbia

\section{FOR CITATION}

Micić, J. (2018) Tourism development and regional disparities in Serbia. R-economy, 4(4), 167-173. doi: $10.15826 /$ recon.2018.4.4.022

\section{Развитие туризма и региональное неравенство в Сербии}

\author{
Я. Мисич \\ Географический институт «Йован Цвиич» Сербской академии наук, Белград, Сербия; \\ e-mail: j.micic@gi.sanu.ac.rs
}

\section{АННОТАЦИЯ}

В данной статье рассмотрены региональные различия и общие национальные тенденции в развитии туризма в Сербии. Сербия обладает богатым и хорошо сохранившимся культурным и природным наследием, а это значит, что страна обладает значительным потенциалом для развития туризма. Наш анализ оценил динамику развития туризма с использованием данных переписи и сосредоточился на таких показателях, как численность населения различных регионов, доля людей, занятых в туризме, доля экономически активного населения и туристический трафик (количество иностранных туристов и ночёвок). Все показатели были проанализированы путем расчета индекса изменения. Результаты показывают, что в Сербии туризм еще не достиг адекватного уровня развития и играет второстепенную роль в экономике страны, хотя он может способствовать демографическому оживлению сербских регионов. Также наблюдается устойчивый рост числа людей, занятых в сфере туризма. Среди других сербских регионов, Белград имеет наиболее процветающую индустрию туризма из-за статуса столицы. Другие регионы также демонстрируют значительный рост трафика иностранных туристов, особенно Златибор, Моравица и Топлица. Адекватное управление и продвижение этих направлений на международном туристическом рынке доказали свою эффективность.

\section{КЛЮЧЕВЫЕ СЛОВА}

туризм, экономическая оценка, несбалансированное региональное развитие, региональные различия, Сербия

\section{ДЛЯ ЦИТИРОВАНИЯ}

Micić, J. (2018) Tourism development and regional disparities in Serbia.

R-economy, 4(4), 167-173. doi: $10.15826 /$ recon.2018.4.4.022 


\section{Introduction}

Tourism is one of the fastest growing industries in the world. The number of tourist arrivals is constantly growing: from 25 million in 1950 to 1,323 million in 2017 (+6.7\% compared to 2016). The sector's share in the global GDP is $10.4 \%$ and the sector provides 313 million jobs ( $9.9 \%$ of total employment or 1 out of 10 jobs) [1]. This growth results from the increased amount of free time, increased mobility of goods and people, and a decrease in transportation costs [2]. The rising economic importance of tourism made it a desirable development prospect for many regions. Tourism impacts income distribution at the global level, but also income circulation between different sectors of national economy [3]. As a labor-intensive activity, tourism creates new jobs and provides workplaces for undereducated people, thus improving their quality of life. It also enhances tax revenues and facilitates economic development [4].

The Republic of Serbia is situated in SouthEastern Europe. The whole territory is divided into five regions (Belgarde, Vojvodina, Šumadija and Western Serbia, South and East Serbia, and Kosovo and Metohija). The regions are further categorized into thirty areas. The country is currently struggling with numerous social, political, and economic issues. Although tourism in Serbia is still in its initial phase of development, it holds significant potential and resources (thermal springs, protected natural areas, UNESCO cultural heritage, historical monuments, gastronomy, etc.), which is not well valorized or promoted. The Tourism Development Strategy (2016-2025) identifies 18 tourism destinations depending on their potential, the current state of tourism infra and supra structure, and significance for the creation of the country's recognizable tourist product [5]. The following tourism products have been chosen as a high priority to be developed by 2021: MICE and business tourism, mountain and lake tourism, city breaks, and spa \& wellness tourism. Medium priority (in 5-10 years) has been given to round trips and nautical tourism, while events, special interest tourism, rural, and transit tourism should be developed continuously as an added value to the tourism development of the whole country [5].

Among the challenges that Serbian tourism currently has to deal with the political and socio-economic situation; the lack of unique tourist product; the low quality of services; unbalanced price-quality ratio; and the outdated infra and supra structure [6]. There are also considerable dif- ferences between the regions in terms of tourism development. The WTTC annual report (2018) confirmed that Serbia ranks quite low on the global tourism market (rank 108/185) [7]. Even though the total number of tourist arrivals and overnight stays in Serbia has been continuously growing, the growth rates still remain low ${ }^{1}$.

\section{Theoretical framework}

Tourism and regional development are closely connected. Tourism is often developed outside of industrialized centers in underdeveloped regions. These regions are usually below the national level according to socio-economic indicators, but they are attractive for tourists. Tourism product is very specific because tourists buy offered experiences, so the consumption and production are inseparable and have to be delivered in a tourist destination [8]. The nature of tourism is very complex as it includes people, their movement, stays, different products and services. Tourism does not represent one economic activity, it is a system that depends on several supporting economies [9]. The complexity of this system determines the effects that tourism has on the region in which it has been developed. Direct effects of tourism could be seen through residents' and non-residents' spending on business and leisure and the government's spending on objects related to tourism industry such as museums and national parks. The indirect or wider impact includes investment in accommodation capacities, the state investment in tourism, funds spent by enterprises that are directly involved in tourism [7]. In addition, tourism has multiplier effects that contribute to the whole regional economy. These effects are more visible than in any other sector and function as economic boosters for underdeveloped regions [9]. Furthermore, the multiplier effect has a higher value in urban than in rural areas because economy in urbanized areas is more diverse [10]. Apart from these positive effects, tourism can also have certain negative consequences, for example, social and environmental. Therefore, policymakers in the sphere of tourism have to solve a complex of problems - how to find a most suitable way to enhance tourism competitiveness on the regional level and how to ensure sustainable tourism development on the national level [11].

Since tourism was recognized as an economic activity, evaluation of its economic effects has

${ }^{1}$ Statistical Office of the Republic of Serbia. (2018). Tourism. Retrieved from http://www.stat.gov.rs/sr-latn/oblasti/ugostiteljstvo-i-turizam/turizam 
started to play a key role in the planning of its development. In theory and practice, there are several different approaches to measuring the impact of tourism on regional or national economy, but none could be considered as optimal [12]. There are such traditional techniques as multiplier analysis, input-output analysis, Keynesian, export-based, ad-hoc models, etc. Their limitations are criticized in research literature on tourism, for example, the biggest problem in the case of input-output analysis is that it focuses on direct effects, overestimates the impacts of tourism on economy or some indicators (e.g. employment) and does not take into account the negative effects which can outweigh the positive ones [13]. Keynesian and export-based models rely on the assumption that tourism provides money injections into the economy of tourist destinations, which means that local households and companies receive extra income and try to save more. Ad-hoc models are based on the input-output and Keynesian models and include the sectors that are relevant for tourism industry [12].

On the other hand, there are new, modern approaches that are more comprehensive, such as computable general equilibrium (CGE) models, macro-econometric modeling, and money generation models (MGM) used for assessment of different economic activities, including tourism (e.g. in Australia, Indonesia, Hawai, Spain, the United Kingdom). CGE models have incorporated input-output analysis and include more indicators for quantitative evaluation of the net impact of changes on output, employment, and imports [13]. The results are more valid and show the impact of tourism on economy more accurately, without exaggerations or misconceptions of tourism as some kind of "magic wand". Macro-econometric modeling requires less data and is simpler for implementation, but cannot explain the relationship between industries within economy [14]. CGE models and macro-econometric modeling are more suitable for larger areas (national level), but input-output analysis and money generation models are better for regional and local levels. MGM models allow to estimate the effects of tourism spendings on employment, income, and tax revenue [15].

\section{Methodology}

As we have pointed out above, there are several models that are commonly used to assess the impact of tourism on economy. These approaches are based on measuring the impacts of interna- tional tourism revenue. Tourism contributes to the revenue of the country of destination, its economic growth, balance of payments, and so on. In Serbia, these effects are calculated by the $\mathrm{Na}$ tional Bank of Serbia (NBS) by using the data on foreign exchange and annual tourism turnover. Economic effects of tourism are also estimated by looking at the data on direct foreign investment in the tourism sector [16]. In 2007-2017, the foreign exchange inflow increased to $84 \%$, while the foreign exchange outflow, to $44 \%$, which means that foreign tourism has become more important for Serbian economy. On the other hand, the Travel \& Tourism Competitiveness Index report (2017) showed a low level of tourism development in Serbia in comparison with other countries of the Balkan Peninsular and Eastern Europe [17].

Even though tourism does not play an important role in Serbian economy, it has been included into the country's development strategies. The significant economic disparities between Serbian regions also affect tourism [18]. The dynamics of tourism development has been assessed with the help of Census data (2002 and 2011) and by analyzing such indicators as the population of different regions, the share of people employed in the tourism industry, the proportion of economically active population, and so on. Since the Statistical Office of the Republic of Serbia does not provide data on the number of people working in the tourism industry, we use the data on those employed in accommodation and food services instead. In order to get a more complete picture of tourism in Serbia, we also use the data on tourism traffic (the number of foreign tourists and overnight stays) for the years of last two censuses and also for the last ten-year period.

All indicators were analyzed by calculating the index of change. The index threshold value is 100 . If the calculated value is higher than 100 , an increase is recorded and if it is lower than 100, then a decline [19]. The data were provided by the Statistical Office of the Republic of Serbia. For the economic and demographic indicators, the census (2002/2011) data were used. The tourism traffic data were collected from the annual publications "Municipalities and Regions of the Republic of Serbia" (2002, 2007, 2011, and 2016).

\section{Results and discussion}

In the last inter-census period, there was recorded a general population decline $(-4.15 \%)$ in Serbia caused by the poor socio-economic situa- 
tion. These results once again confirmed that Serbia has been facing depopulation for a long time. The strategies aimed at addressing this issue often mention tourism as a revitalization factor even though there is evidence that in some cases tourism may have a negative impact on population dynamics. In other cases, however, tourism stimulated demographic growth, reduced the outflow of workforce to other regions and helped attract migrants (e.g. Spain, Greece), but it still cannot be seen as a universal strategy [20]. Additionally, population decline from $-1.42 \%$ to $-30.13 \%$ was detected in all regions, except Belgrade, where a slight increase was recorded $(+5.29 \%)$ due to migration.
Furthermore, at the local level, there was a population increase in Belgrade, South Bačka, and Raška. In Belgrade and South Bačka, this growth can be explained by the fact that migrants are attracted by the largest Serbian cities located in these regions the capital and the main administrative center Vojvodina. In Raška, the population growth could be a result of the traditional reproductive model of the local community. Thus, it can be concluded that in Serbia, tourism has not reached the level of development that would generate population growth. Together with the overall population decline, there is also a decrease in the economically active population $(-35.92 \%$ to $-1.975 \%)$ (see Table 1$)$.

Index of change of demographic and economic indicators (2011/2002)

\begin{tabular}{|c|c|c|c|c|}
\hline Region & Total population & Economically active population & Secondary sector & Tourism \\
\hline Serbia & 95.85 & 87.2 & 69.06 & 106.85 \\
\hline Belgrade region & 105.29 & 106.65 & 82.56 & 132.54 \\
\hline Belgrade area & 105.29 & 106.65 & 82.56 & 132.54 \\
\hline Vojvodina region & 95.07 & 86.62 & 76.83 & 104.08 \\
\hline North Bačka area & 93.39 & 84.65 & 71.91 & 109.76 \\
\hline Centra Banat area & 90.03 & 78.05 & 71.89 & 83.80 \\
\hline North Banat area & 89.08 & 79.04 & 72.36 & 77.95 \\
\hline South Banat area & 93.56 & 79.98 & 72.41 & 102.35 \\
\hline West Bačka area & 87.89 & 77.25 & 62.87 & 71.68 \\
\hline South Bačka area & 103.66 & 98.03 & 81.64 & 125.07 \\
\hline Srem area & 92.97 & 88.50 & 92.14 & 110.25 \\
\hline Šumadija and Western Serbia region & 95.08 & 82.78 & 74.68 & 102.11 \\
\hline Mačva area & 90.69 & 76.11 & 79.44 & 85.36 \\
\hline Kolubara area & 90.80 & 89.97 & 95.63 & 100.34 \\
\hline Šumadija area & 98.17 & 85.81 & 76.92 & 110.45 \\
\hline Pomoravlje area & 94.33 & 77.37 & 70.05 & 111.07 \\
\hline Zlatibor area & 91.43 & 86.02 & 70.63 & 94.95 \\
\hline Moravica area & 94.59 & 83.88 & 69.96 & 103.94 \\
\hline Raška area & 106.19 & 87.03 & 75.61 & 112.25 \\
\hline Rasina area & 93.28 & 77.62 & 67.86 & 102.32 \\
\hline South and East Serbia region & 89.21 & 75.68 & 65.57 & 87.01 \\
\hline Podunavlje area & 94.82 & 76.25 & 75.69 & 79.30 \\
\hline Braničevo area & 91.58 & 72.59 & 82.05 & 100.23 \\
\hline Bor area & 85.29 & 73.27 & 61.03 & 69.95 \\
\hline Zaječar area & 87.21 & 86.31 & 57.69 & 97.63 \\
\hline Nišava area & 98.58 & 82.94 & 70.50 & 101.33 \\
\hline Toplica area & 89.89 & 69.46 & 61.25 & 65.04 \\
\hline Pirot area & 87.53 & 71.72 & 57.19 & 83.29 \\
\hline Jablanica area & 89.78 & 76.20 & 59.38 & 85.34 \\
\hline Pčinja area & 69.87 & 64.08 & 59.66 & 76.27 \\
\hline Kosovo and Metohija ${ }^{*}$ & - & - & - & - \\
\hline
\end{tabular}

Sourse: 2002 Census of Population, Households and Dwellings in the Republic of Serbia. Population. Age and Sex. Belgrade: Statistical Office of the Republic of Serbia. Retrieved from http://publikacije.stat.gov.rs/G2002/Pdf/G20024002.pdf; 2002 Census of Population, Households and Dwellings in the Republic of Serbia. Population. Economically Active Population That Perform Occupation. Belgrade: Statistical Office of the Republic of Serbia. Retrieved from http://publikacije.stat.gov.rs/G2002/Pdf/G20024006.pdf; 2011 Census of Population, Households and Dwellings in the Republic of Serbia, Population. Age and Sex. Belgrade: Statistical Office of the Republic of Serbia. Retrieved from http://pod2.stat.gov.rs/ObjavljenePublikacije/Popis2011/Starost\%20i\%20pol-Age\%20and\%20sex.pdf; 2011 Census of Population, Households and Dwellings in the Republic of Serbia. Industry Data by Municipalities and Cities. Belgrade: Statistical Office of the Republic of Serbia. Retrieved from http://pod2.stat.gov.rs/ObjavljenePublikacije/G2014/pdf/G20144002.pdf.

Note: * The data about Kosovo and Metohija are not available due to the current political situation. 
In those regions and areas where tourism plays the dominant role, the tertiary sector employs a considerable share of the economically active population and affects the development of supporting industries [20]. It determines these regions' transition from the dominant primary and secondary to the tertiary sector.

Serbia has recorded a constant decline in the number of employees in the secondary sector $(-30.94 \%)$ due to the recession that the country's economy entered after the collapse of Yugoslavia in the 1990s. There are some more recent issues to deal with: most large formerly stateowned factories in Serbia have been privatized and are now struggling or closing down, which aggravated the situation in the secondary sector. Furthermore, in the last inter-census period, the number of people employed in the secondary sector decreased across the country. The smallest decline was recorded in the capital - Belgrade region. On the other hand, during this decade, there was an increase in the number of people employed in tourism $(+6.85 \%)$. The most significant growth was again found in Belgrade region $(+32.54 \%)$, much higher than the national average; in Vojvodina region (4.08\%); and Šumadija and Western Serbia (2.11\%). There was, however, an almost $23 \%$ decrease in South and East Serbia. This situation can hardly be called surprising because South and East Serbia has long been known to be the least developed part of the country and also the most depopulated. If we look at the share of people employed in the secondary sector $(20-29 \%)$ and in tourism $(2-4 \%)$ and at the corresponding index of changes, we can see that the percentage of people employed in the tourism sector is still low in all the regions although there is a positive trend, which indicates the growing importance of tourism, especially in Zlatibor (3.9\%), Belgrade (3.48\%), and South Bačka (3.18\%).

Another key indicator of tourism development in Serbia is tourism traffic (see Table 2). We used the data on foreign tourist arrivals and overnight stays for the periods of 2011/2002 and $2007 / 2016$ because the foreign exchange data are used by the NBS in their evaluation of the tourism impact on Serbian economy. In terms of tourism traffic, Belgrade again occupies a dominant position (over $50 \%$ of the total foreign tourism traffic), which can be explained by the location of the main airport in this region and the city's status of the capital.
Table 2

Foreign tourism traffic: index of change in $2011 / 2002$ and $2016 / 2007$

\begin{tabular}{|c|c|c|c|c|}
\hline \multirow[b]{2}{*}{ Region } & \multicolumn{2}{|c|}{$2011 / 2002$} & \multicolumn{2}{|c|}{$2016 / 2007$} \\
\hline & $\begin{array}{l}\text { Tou- } \\
\text { rists }\end{array}$ & $\begin{array}{l}\text { Over- } \\
\text { night } \\
\text { stays }\end{array}$ & $\begin{array}{l}\text { Tou- } \\
\text { rists }\end{array}$ & $\begin{array}{l}\text { Over- } \\
\text { night } \\
\text { stays }\end{array}$ \\
\hline Serbia & 244.88 & 222.56 & 184.10 & 185.61 \\
\hline Belgrade region & 230.69 & 199.85 & 169.08 & 169.40 \\
\hline Belgrade area & 230.69 & 199.85 & 169.08 & 169.40 \\
\hline Vojvodina region & 241.93 & 252.51 & 206.32 & 201.09 \\
\hline North Bačka area & 260.63 & 236.88 & 281.57 & 220.93 \\
\hline Centra Banat area & 228.15 & 338.96 & 222.85 & 291.56 \\
\hline North Banat area & 272.04 & 356.43 & 95.13 & 70.07 \\
\hline South Banat area & 178.07 & 151.53 & 151.31 & 141.61 \\
\hline West Bačka area & 181.45 & 139.96 & 94.52 & 70.80 \\
\hline South Bačka area & 267.81 & 285.76 & 214.50 & 228.82 \\
\hline Srem area & 131.37 & 131.48 & 241.98 & 306.84 \\
\hline $\begin{array}{l}\text { Šumadija and Western } \\
\text { Serbia region }\end{array}$ & 303.66 & 264.81 & 224.98 & 215.45 \\
\hline Mačva area & 84.84 & 104.17 & 237.45 & 191.41 \\
\hline Kolubara area & 278.86 & 278.76 & 118.10 & 106.39 \\
\hline Šumadija area & 396.02 & 370.85 & 263.71 & 263.09 \\
\hline Pomoravlje area & 397.74 & 610.95 & 86.56 & 104.27 \\
\hline Zlatibor area & 429.76 & 408.61 & 273.27 & 237.12 \\
\hline Moravica area & 303.82 & 412.46 & 195.82 & 253.48 \\
\hline Raška area & 260.83 & 203.99 & 256.56 & 215.06 \\
\hline Rasina area & 339.68 & 331.71 & 144.17 & 178.98 \\
\hline $\begin{array}{l}\text { South and East Serbia } \\
\text { region }\end{array}$ & 258.00 & 237.63 & 190.15 & 206.09 \\
\hline Podunavlje area & 146.93 & 147.95 & 61.45 & 91.13 \\
\hline Braničevo area & 277.90 & 159.52 & 312.91 & 261.77 \\
\hline Bor area & 323.15 & 298.57 & 235.21 & 225.27 \\
\hline Zaječar area & 200.47 & 230.15 & 339.18 & 262.66 \\
\hline Nišava area & 358.69 & 323.56 & 173.21 & 190.11 \\
\hline Toplica area & 1246.64 & 907.20 & 410.64 & 472.31 \\
\hline Pirot area & 76.08 & 108.95 & 299.96 & 315.52 \\
\hline Jablanica are & 230.09 & 208.92 & 196.63 & 216.97 \\
\hline Pčinja area & 153.48 & 144.63 & 166.49 & 133.99 \\
\hline Kosovo and Metohija & - & - & - & \\
\hline
\end{tabular}

Sourse: Municipalities of the Republic of Serbia (2004). Belgrade: Statistical Office of the Republic of Serbia. Retrieved from http://publikacije.stat.gov.rs/G2003/Pdf/G20032002.pdf; Municipality of the Republic of Serbia (2008). Belgrade: Statistical Office of the Republic of Serbia Retrieved from http:// publikacije.stat.gov.rs/G2008/Pdf/G20082001.pdf; Municipality and Regions of the Republic of Serbia (2012). Belgrade: Statistical Office of the Republic of Serbia Retrieved from http:// publikacije.stat.gov.rs/G2012/Pdf/G20122008.pdf; Municipality and Regions of the Republic of Serbia (2017). Belgrade: Statistical Office of the Republic of Serbia Retrieved from http:// publikacije.stat.gov.rs/G2017/Pdf/G201713044.pdf.

In addition, in both periods, there was a significant increase in the number of foreign tourists and overnight stays (around 200\%). The highest steady growth has been found in Šmadija and Western Serbia, especially in Zlatibor and Mora- 
vica. Tourism development in these two areas follows the general national trends, but it also results from the efforts of the Regional Tourism Organization of Western Serbia, which operates in these two areas. The Organization successfully promotes the region as a unique destination on the tourism market. Additionally, Toplica in South and East Serbia has shown a considerable growth in foreign tourism traffic. This region has been attractive for domestic tourists for a long time, but it became visible to the international audience in 2002 when Natural Monument Djavolja Varoš (Kuršulmija) was submitted for admission to the UNESCO's list by the Institute for the Protection of Nature of Serbia. The monument is still on the tentative list but already represents one of the national symbols [21]. In 2015, an airport was opened in Niš, which also positively affected the foreign tourism traffic in Toplica.

\section{Conclusion}

In Serbia, a country with rich natural and cultural heritage, tourism has been regarded as a part of the general strategy of national economic development: not only does it create jobs for people with different levels of education but it also uses the products and services provided by other sectors of economy. Our analysis, however, has shown that tourism does not play a primary role in Serbian economy although the number of people employed in this sector has been growing steadily. The development of tourism in Serbian regions led to greater diversification of regional economy, enhanced economic security, raised the quality of life of local communities through investment in the infra and supra-structure [22]. The data on foreign tourism traffic once again confirmed that there are positive trends in tourism development in Serbian regions. The dominance of Belgrade region as a tourism destination is obvious, so the decision-makers should promote dispersive development of tourism and implement other policies to ensure more balanced regional development. By promoting their tourist sites on the international market, Zlatibor, Moravica, and Toplica have also managed to achieve some positive results. Other Serbian regions could benefit from this experience and increase their visibility on the international tourism market with the help of an efficient promotion campaign. Despite the objective limitations faced by tourism in Serbia, creation of regional tourism organizations would facilitate promotion and positioning of a recognizable tourism product both on national and international levels; it would also boost small and medium-sized entrepreneurship in regions.

\section{References}

1. World Tourism Organization (2018). UNWTO Tourism Highlights. Madrid. doi: $\underline{10.18111 / 9789284419876}$

2. Saarinen, J. (2003). The Regional Economics of Tourism in Northern Finland: The Socio-economic Implications of Recent Tourism Development and Future Possibilities for Regional Development. Scandinavian Journal of Hospitality and Tourism, 3(2), 91-113. doi: 10.1080/15022250310001927

3. Bošković, T. (2009). Tourism as a Factor of Economic Development. Škola biznisa, 2, 23-28. (In Serbian).

4. Pratt, S. (2015). Potential Economic Contribution of Regional Tourism Development in China: A Comparative Analysis. International Journal of Tourism Research, 17(3), 303-312. doi: $\underline{10.1002 / \text { jtr. } 1990}$

5. Ministry of Trade, Tourism and Telecommunications. (2016). Tourism Development Strategy of the Republic of Serbia 2016-2025. Belgrade: Ministry of Trade, Tourism and Telecommunications. Retrieved from http://mtt.gov.rs/download/3/TOURISM\%20DEVELOPMENT\%20STRATEGY\%20OF\%20RS\%202016-2025.pdf (In Serbian).

6. Ministry of the Environment, Mining and Spatial Planning. (2010). Law on Spatial Planning of the Republic of Serbia from 2010 to 2020. Official Gazette of the Republic of Serbia, no. 88/10. Retrieved from http://195.222.96.93//media/PI_PPRS_2011-2015.pdf (In Serbian).

7. World Travel \& Tourism Council (2018). Travel \& Tourism Economic Impact 2018 Serbia. Retrieved from https://www.wttc.org/-/media/files/reports/economic-impact-research/countries-2018/serbia2018.pdf

8. Surugiu, C., \& Surugiu, M. R. (2013). Is the Tourism Sector Supportive of Economic Growth? Empirical Evidence on Romanian Tourism. Tourism Economics, 19(1), 115-132. doi: 10.5367/ te.2013.0196 
9. Li, H., Gohb, C., Zhang Qiu, H., \& Menga, F. (2014). Effect of Tourism on Balanced Regional Development: A Dynamic Panel Data Analysis in Coastal and Inland China. Asia Pacific Journal of Tourism Research, 20(6), 694-713. doi: 10.1080/10941665.2014.930055

10. Zhang, J., Madsen, B., \& Jensen-Butler, C. (2007). Regional Economic Impacts of Tourism: The Case of Denmark. Regional Studies, 41(6), 839-854, doi: 10.1080/00343400701281733

11. Petrevska, B., \& Gerasimova, V. M. (2012). Tourism in Regional Development: Empirical Evidence. Innovative Issues and Approaches in Social Sciences, 5(2), 6-20. doi: 10.12959/issn.18550541.IIASS-2012-no2-art01

12. Kumar, J., \& Husain, K. (2014). Evaluating Tourism's Economic Effects: Comparison of Different Approaches. Procedia - Social and Behavioral Sciences, 144, 360-365. doi: 10.1016/j.sbspro.2014.07.305

13. Dwyer, L., Forsyth, P., \& Spurr, R. (2004). Evaluating Tourism's Economic Effects: New and Old Approaches. Tourism Management, 25(3), 307-317. doi: 10.1016/S0261-5177(03)00131-6

14. Li, S., Blake, A., \& Thomas, R. (2013). Modeling the Economic Impact of Sports Events: The Case of the Beijing Olympics. Economic Modelling, 30, 235-244. doi: 10.1016/j.econmod.2012.09.013

15. Horwath Consulting. (2012). Predlog modela optimalnog upravljanja turizmom sa organizacionom strukturom turističke regije Zapadna Srbija. Zagreb: Horwath Consulting. Retrieved from http://www.rrazlatibor.co.rs/psd/publikacije/predlog modela.pdf (In Serbian).

16. Petković, G., Zečević, B., \& Pindžo, R. (2011). Tourism as a part of national economy. Ekonomika preduzeća, 59(1-2), 89-97. doi: 10.5937/ekopre1102089P (In Serbian).

17. World Economic Forum. (2017). The Travel \& Tourism Competitiveness Report 2017: Paving the Way for a More Sustainable and Inclusive Future. Retrieved from http://www3.weforum.org/docs/ WEF TTCR 2017 web 0401.pdf

18. Gaijić, T., Vujko, A., \& Kocić, V. (2014). Determination of Inter-Regional Disparities in the Development of Serbian Tourism. Ekonomski signali: poslovni magazine, 9(1), 113-129. doi: 10.5937/ ekonsig1401113G (In Serbian).

19. Stojanović, J., Kokotović-Kanazir, V., \& Stojanović, M. (2017). Does Small Town with Touristic Function have Demographic Potential? Journal of the Geographical Institute "Jovan Cvijic" SASA, 67(2), 145-162. doi: $10.2298 /$ IJGI1702145S

20. Devedzić, M. (2007). Effects of Tourism on Population Development. Stanovništvo, 2, 63-79. doi: 10.2298/0038-982X(2007) (In Serbian).

21. Bjeljac, Ž., Brankov, J., Jovičić, D., Ćurčić, N., \& Terzić, A. (2012). Valorization of Natural and Anthropogenic Tourist Potentials in Underdeveloped Regions of Transition Countries. TTEM, $8(3), 1237-1250$.

22. Loukissas, P. J. (1982). Tourism's Regional Development Impacts: A Comparative Analysis of the Greek Islands. Annals of Tourism Research, 9(4), 523-541. doi: 10.1016/0160-7383(82)90071-8

\section{Information about the author}

Jasna Micić - M.Sc. in Tourism, Research Assistant, Geographical Institute Jovan Cvijić of the Serbian Academy of Sciences and Arts (SASA) (Djure Jakšića 9, 11000 Belgrade, Serbia); e-mail: j.micic@gi.sanu.ac.rs. 